Institute of $\mathbf{F}_{\text {ood and }} \mathbf{A}_{\text {gricultural }} \mathbf{S}_{\text {ciences }}$

\title{
Your Florida Dooryard Citrus Guide - Pruning ${ }^{1}$
}

James J. Ferguson ${ }^{2}$

Although large machines prune closely planted trees in commercial citrus groves on a regular basis, dooryard citrus need not be pruned at all. There are exceptions: aesthetic purposes, to prevent shading of other plants, to prevent soilborne diseases, to remove cold-damaged limbs, and to rejuvenate old trees with reduced vigor, twig and small branch dieback, and small fruit.

If you are pruning to rejuvenate, prune a short time before a major growth flush. The more you cut, the greater the stimulation because the undisturbed root system now provides the same amount of water and nutrients to a reduced canopy. This effect is greatest in the parts of the tree where the most severe cuts are made, so the pruned tree tends to regain its natural shape. The severity of your pruning should be related to the amount of growth stimulation needed to restore vigor and fruit production.

Less pruning is required when the cause of the decline can be corrected by other means or when extra care can provide some of the needed revitalization. Rejuvenation pruning is not always successful, and it is best to replace the tree if the desired response is not obtained.
The best time for severe pruning is after the danger of freezing temperatures is past and just before the spring growth flush. At this time new foliage will grow rapidly to cover exposed limbs. Bark that has grown in the shade is easily sunburned and may be killed in severe cases. Never prune trees drastically when they are suffering from drought.

\section{Removing Large Tree Branches}

Large branches too heavy to be held by hand (1 $1 / 2$ inches or more in diameter) require three separate cuts to prevent trunk bark stripping (Figure 1). The first cut is made on the underside of the branch about 15 inches away from the trunk and as far up through the branch as possible before the branch weight binds the saw. The second cut is made downward from the top of the branch about 18 inches from the main trunk to cause the limb to split cleanly between the two cuts without tearing the bark. The remaining stub can be supported easily with one hand while it is cut from the tree. This final cut should begin on the outside of the tree bark ridge and end just outside of the branch collar swelling on the lower side of the branch (Figure 2). (The bark ridge is usually rough, always darker than the surrounding bark and fairly obvious on most species.) Note that the cut is usually made angling down and outward from the tree. If the cut

1. This document is HS 889, one of a series of the Horticultural Sciences Department, Florida Cooperative Extension Service, Institute of Food and Agricultural Sciences, University of Florida. Originally published in hardcopy,1995. Publication date: August, 2002. Please visit the EDIS Web site at http://edis.ifas.ufl.edu.

2. James J. Ferguson, professor, Horticultural Sciences Department, Cooperative Extension Service, Institute of Food and Agricultural Sciences, University of Florida, Gainesville, 32611.

The Institute of Food and Agricultural Sciences is an equal opportunity/affirmative action employer authorized to provide research, educational information and other services only to individuals and institutions that function without regard to race, color, sex, age, handicap, or national origin. For information on obtaining other extension publications, contact your county Cooperative Extension Service office. Florida Cooperative Extension Service/Institute of Food and Agricultural Sciences/University of Florida/Christine Taylor Waddill, Dean. 
must be made straight down (parallel to the trunk), do not make it flush with the tree trunk. A flush cut will cause serious injury. Although this was once standard practice, research has conclusively shown that flush cuts cause extensive trunk decay because wood that is actually part of the trunk gets cut. When the bottom of the branch collar is hard to see, prune as shown in Figure 3. In this way, only branch tissue is cut, and there is no damage to the trunk.
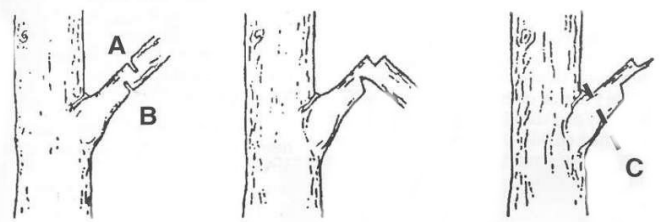

Figure 1. Removing a branch over $11 / 2$ inch diameter. First $(A)$ and second $(B)$ cuts prevent bark from tearing. Third cut $(C)$ detailed in Figures 2 and 3.

-..-- POSITION OF CUT

..... BOUNDRY BETWEEN TRUNK TISSUE AND BRANCH TISSUE
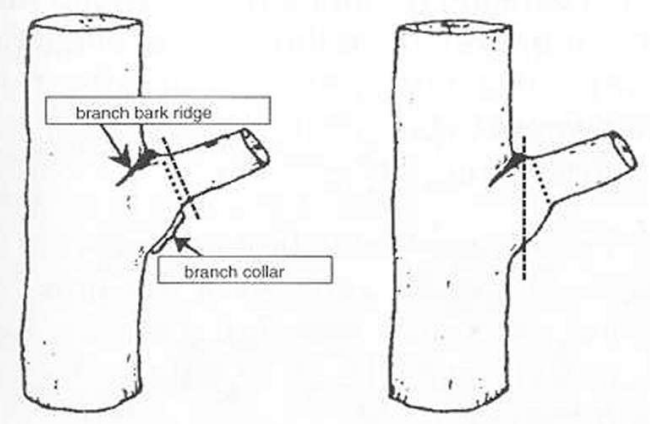

Figure 2. Correct (left) and incorrect (right) final pruning cuts for branches of any size.

Painting wounds with tree wound dressing has become a controversial practice. The standard recommendation was to paint wounds with a quality tree wound dressing to protect the surface from wood rotting organisms and from cracking upon drying. However, research has shown that wound dressings do not prevent decay. When exposed to the sun, the protective coating often cracks, allowing moisture to enter and accumulate in pockets between the wood and wound covering. This situation may be more inviting to wood rotting organisms than one with no wound covering. In situations where aesthetics are important, the practice may be justified.

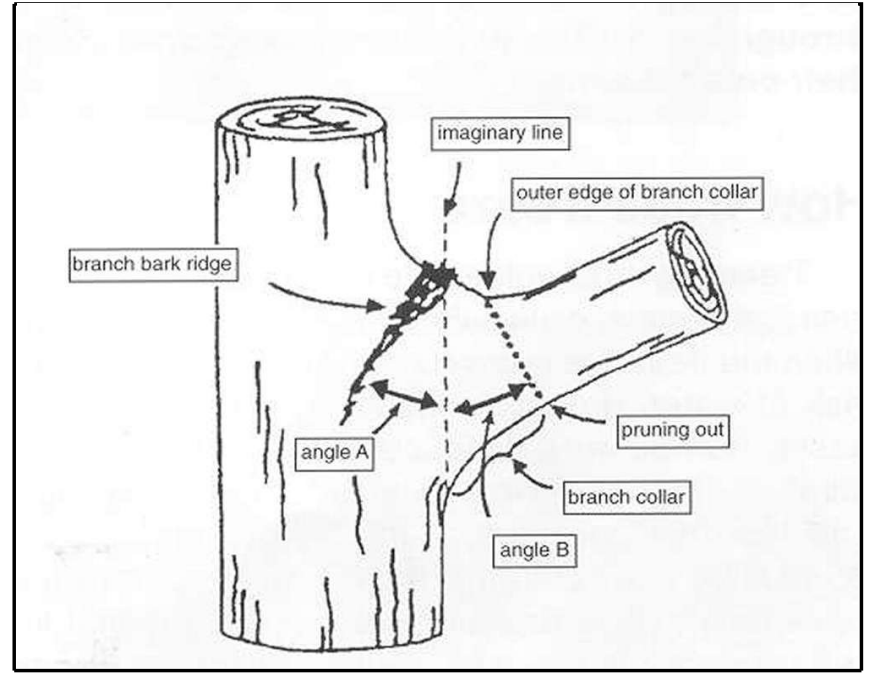

Figure 3. When the bottom of the branch collar cannot be seen from above the branch, the angle of the cut can be estimated. Think of an angle $(A)$ created by the branch bark ridge and an imaginary line flush with the tree trunk. Duplicate that angle (B) in the branch to be trimmed and then make the pruning cut.

After a severe freeze that causes damage to major limbs, wait several months to prune. During the spring flush following a freeze, leaves on freeze-damaged limbs may grow but then will wilt soon after. After this wilt occurs on the spring flush, you will have a better idea about which limbs to prune. However, limbs with minor cold damage and split bark can continue to reduce fruit production for months, and even years, after a freeze.

Sometimes when a tree is weak, frozen back or broken off, a sucker or shoot will grow from the rootstock. The fruit from this rootstock shoot will usually be different than on the original tree. (The tree may produce two kinds of fruit if a portion of the scion remains. Fruits from rootstocks may be sour orange, rough lemon, trifoliate orange, Carrizo citrange, or Swingle citrumelo or other rootstocks.) Cut the sucker off to allow the desired variety to become dominant.

If your tree is completely destroyed, it is usually better to plant a new tree of the desired variety than to try to bud the rootstock. If youre thinking of moving a mature tree to a different location, it is also usually more economical to plant a new tree in the site. 


\section{Cold Tolerance}

Although citrus trees are cold-tender plants of subtropical and tropical origin and have not developed the effective cold hardening processes typical of temperate, woody, deciduous species, they have the capability for acquiring considerable cold tolerance. Citrus does not enter a deep dormancy (resting condition) characteristic of temperate-zone deciduous tree species such as apples or peaches. Rather, citrus enters a period of nonapparent growth (quiescence) as cooler temperatures (approximately two weeks of $40-60^{\circ} \mathrm{F}$ ) occur.

Cold tolerance develops most readily when trees are not flushing (producing new leaves). Severely pruning dooryard trees during the late fall or winter months can reduce the size of the canopy, limiting its heat retaining capacity and stimulating untimely growth of tender flushes. The healthier, less injured, and less stressed trees are, the more they respond to cooler temperatures that induce quiescence.

In general, the degree of cold tolerance acquired by a tree is influenced by environmental conditions mainly cool temperatures - as well as by tree health, its rootstock, and scion. Maximum cold tolerance ordinarily develops in citrus in the northern part of the state because of lower average winter temperatures, compared with citrus growing in the southern areas and along the coasts. But warm temperatures at any time during the winter may cause citrus trees throughout the state to resume growth and reduce their cold tolerance.

\section{How Trees Freeze}

Trees are most vulnerable to cold damage during their first 5 years, especially during growth flushes and when the trees are recovering from stress caused by lack of water, drought conditions, diseases, insect pests, nutritional deficiencies, and previous cold damage. Parts of the tree exposed to the atmosphere and the smallest parts of the tree (twigs, leaves, developing fruit) cool the fastest and are the most vulnerable to cold damage. Flowers are the first tissues to freeze, followed by tender, new growth (leaves and twigs), then older fully mature growth, small-diameter wood, and then large-diameter wood, with the trunk being the last to freeze.
Young, developing fruit tends to freeze before mature fruit and smaller size fruit before larger fruit of equal maturity. Fruit with thin peel tends to freeze sooner than fruit with thick peel. As a rule of thumb, citrus trees generally freeze from the top to bottom and from the outside to the inside of the tree.

Ice formation in citrus tissues - not low temperatures as such - kills or damages citrus trees and fruit. However, tissue where ice forms does not always die. The critical temperature for ice forming in citrus tissues is approximately $28^{\circ} \mathrm{F}$, except when trees are in bloom and/or visible frost (frozen dew) occurs. Because of a phenomenon called supercooling, citrus flowers, fruit, leaves, and wood sometimes have the ability to supercool (to exist in an unfrozen, undamaged state below critical freeze temperatures) to as low as $16^{\circ} \mathrm{F}$ in leaves and $10^{\circ}$ $\mathrm{F}$ in fruit, depending on the severity and duration of the freezing temperatures.

Satsuma trees on trifoliate orange rootstock demonstrate perhaps the greatest freeze survival among commercial citrus cultivars, having frequently survived temperatures of $14^{\circ} \mathrm{F}$ with only slight injury when adequately cold hardened. Common cultivars of sweet orange, other mandarins and grapefruit cannot withstand such low temperatures. Citrus flowers will freeze at about $28^{\circ} \mathrm{F}$; fruit damage occurs when the temperature falls below $28^{\circ}$ $\mathrm{F}$ for at least 4 hours. Even frozen fruit can be salvaged for juice. Within several days after a severe freeze, commercial growers harvest frozen fruit to obtain at least some return for their frozen fruit from juice processors.

\section{Soil Banking}

Soil banking (mounding soil around the trunk of a young tree, even up to the lower scaffold branches) is perhaps the cheapest, most effective way for homeowners to protect the trunk of young citrus trees from cold damage (Figure 4).

If the exposed portion of the tree is frozen, a new canopy will quickly grow from the protected portion after the soil is removed in the spring. Although soil banks can provide $12-15^{\circ} \mathrm{F}$ cold protection, they do have drawbacks. 


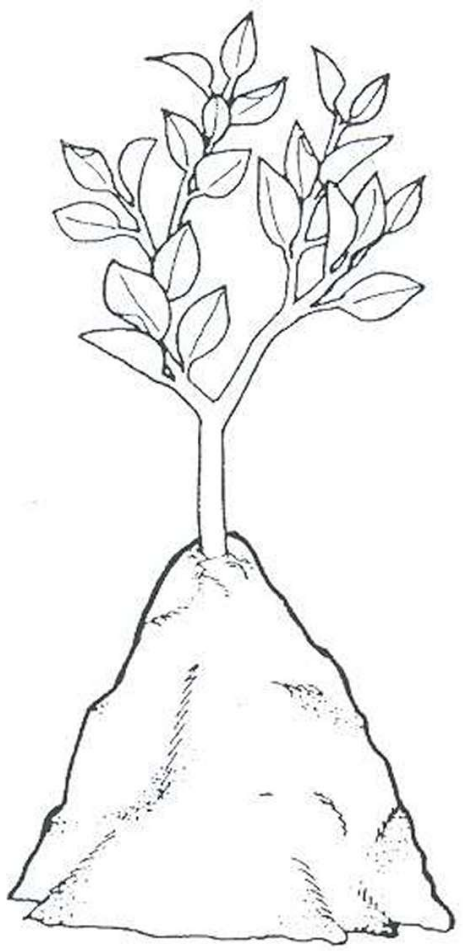

Figure 4. A typical soil bank.

Soil banks must be constructed before freezes occur (usually by mid-December) and removed as soon as possible after the seasonal threat of cold has passed (usually by mid-March). However, periods of warm winter temperatures may necessitate early removal of at least a small portion of the bank before the danger of cold has passed.

Banks may have to be reconstructed periodically because of erosion from rainfall and irrigation. Some labor is involved in construction and removal of the soil bank. Unless you're careful, mounding and removing the soil with a hoe, rake or shovel may damage the tree trunk, predisposing it to insect and disease problems. Undetected, diseases like foot rot may develop and pest infestations may occur within the soil bank until the tree is severely damaged.

You can build a bank using a shovel or hoe and soil that is free of weeds, sticks, bags or other trash: these invite damage from both pests and disease. Build your banks as high as possible, up into the scaffold limbs when possible. Monitor banks during winter as wind and rain may erode the banks, leaving the tree vulnerable to cold.

Fungal diseases like foot rot sometimes occur when soil is mounded against the more susceptible scion portion of a young citrus tree. If you apply a suitable fungicide before banking, it will help reduce the incidence of this disease.

Trees can be safely unbanked as soon as the danger of cold has passed. In most areas this will be in mid- to late-February. If you leave banks on your trees too long in warm weather, disease and insect problems increase. There is also danger of a physiological bark-sloughing disorder that can quickly kill a young tree.

Many regions in Florida have such a low cold damage probability that banks may not even be justified. Indeed, commercial citrus growers in much of south Florida do not bank trees at all. Growers in north and much of central Florida realize there is a high probability of cold damage and routinely bank young trees in the fall or use tree wraps as a regular production practice. Homeowners wishing to estimate the probability of the first and last freeze occurrence in Florida should consult Figure 5 and Figure 6.

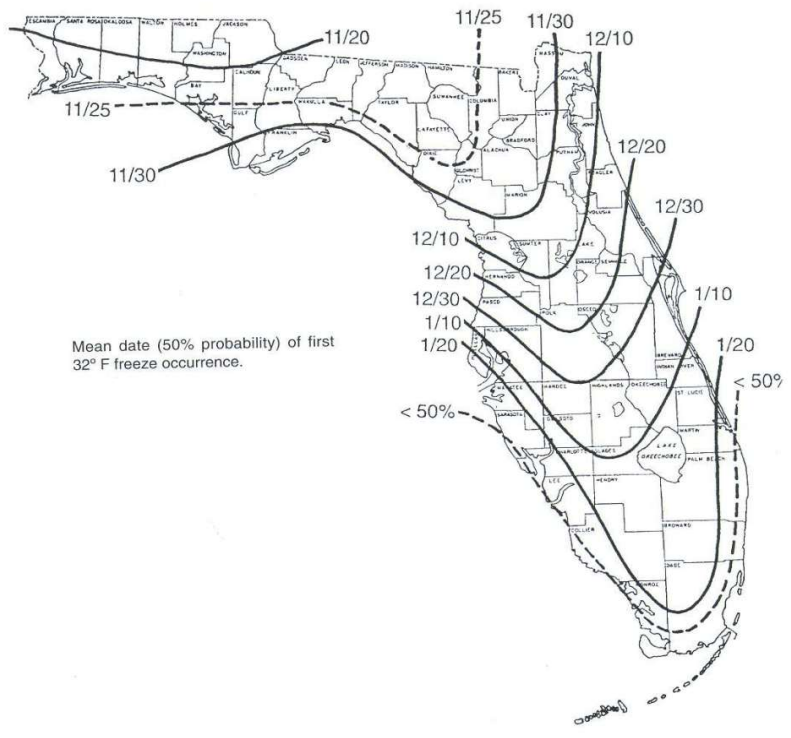

Figure 5. Mean date (50\% probability) of first $32^{\circ} \mathrm{F}$ freeze occurrence.

\section{Microsprinklers}

If you already use microsprinklers for irrigation, you can use them for cold protection for both young and mature trees. Check first on water use restrictions 


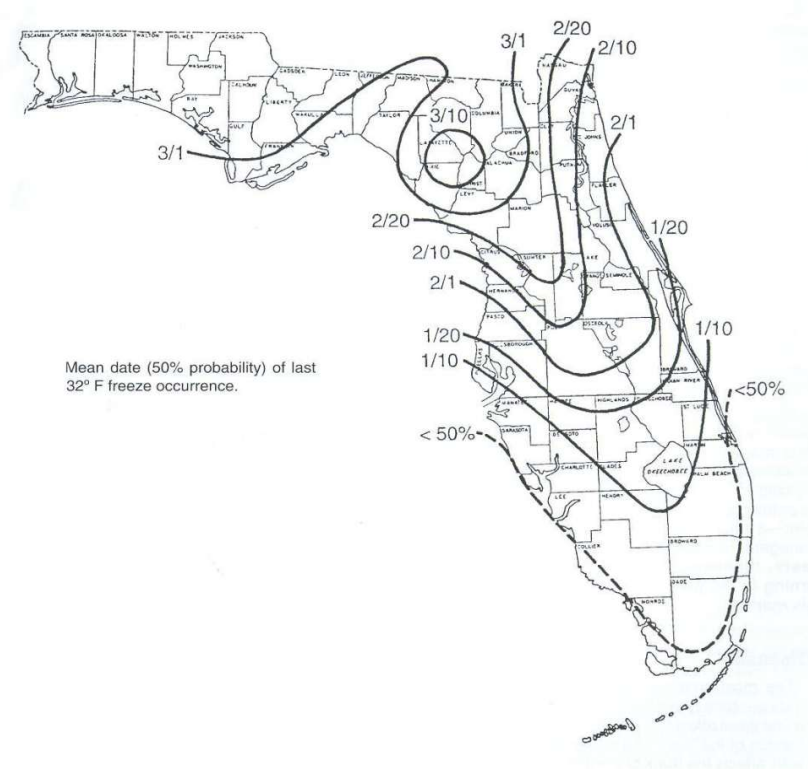

Figure 6. Mean date ( $50 \%$ probability) of last $32^{\circ} \mathrm{F}$ freeze occurrence.

that in some parts of the state may limit such applications.

\section{Commercial Practices}

In commercial groves both ground water and surface water are used for irrigation and cold protection. When ground water with a temperature of $68-80^{\circ} \mathrm{F}$ is applied to very young trees through microsprinklers during freezes, the heat stored in the water is released as this water turns into ice. If enough water is continuously applied, especially during windy freezes, the temperature of the citrus tissue beneath the ice will not drop much below $32^{\circ} \mathrm{F}$. When the ice thaws, tissue covered with ice will be undamaged. Commercial growers are also now elevating microsprinklers to a height of 4 feet or more next to the trunk of mature trees to provide cold protection for as much of the canopy and branches of mature trees as possible.

In practice, growers place microsprinkler emitters approximately a yard away from the young tree on the northwest side of the tree, the direction of prevailing winds during most Florida freezes. Using a $90^{\circ}$ spray pattern, they concentrate water on the trunk of young trees at the rate of 10-15 gallons per hour. When microsprinklers with a circular spray pattern are placed within mature trees, downward pointing spokes of water will offer good protection.
(Some limb breakage may occur from ice loading, but this is unavoidable.)

\section{Home Irrigation Systems}

\section{A microsprinkler irrigation system for home} use would include an in-line water filter, $1 / 2$ to $3 / 4$ inch plastic irrigation tubing with a circular clamp to constrict the folded end of the tubing, and a pre-assembled microsprinkler unit. Such setups are available retail at irrigation supply stores. For further information consult your county extension agent. 